dominatin $\gamma$ microflora. Their presence is more irregular from the and week and, after weaning they disappear from the small gut and show a level between $10^{2}$ and $10^{4} / \mathrm{g}$ in the cæcum and colon. The Clostridia only appear after weaning and exclusively in the cæcum and colon $\left(10^{3}-10^{5} / g\right)$.

Although this study is still incomplete it can already be concluded that the rabbit has a very original microflora because of its dominating strict anaerobic character, the absence of Lactobacilli, and the low population density in the stomach despite the coprophagy.

\title{
URÉOLYSE PAR DIFFÉRENTES BAGTÉRIES « IN VITRO » ET « IN VIVO » DANS LE TUBE DIGESTIF DE RATS « GNOTOXÉNIQUES ». INFLUENCE DE L'IMMUNISATION
}

\author{
Marie-Christiane MOREAU, R. DUCLUZEAU et P. RAIBAUD \\ Labovatoire d'Écologie microbienne, \\ Centre national de Recherches zootechniques, $I$. N. R. A., \\ 78350 Jouy en Josas
}

Le rat axénique excrète dans ses fèces environ $40 \mathrm{mg}$ d'urée pour roo $\mathrm{g}$ de fèces fraîches alors qu'on ne trouve pas d'urée dans les fèces d'animaux holoxéniques. Nous avons donc cherché à savoir quelles étaient les souches bactériennes présentes dans le tube digestif des holoxéniques qui sont responsables de cette uréolyse. Par ailleurs, nous avons essayé de modifier cette activité uréolytique par des moyens immunologiques.

I $^{\circ}$ On a isolé du tube digestif de rats holoxéniques une souche de Lactobacillus et une souche d'Actinobacillus qui sont uréolytiques in vitro. On ensemence le tube digestif de rats axéniques avec chacune de ces 2 souches, et on suit la cinétique d'hydrolyse de l'urée dans leurs fèces.

Chez le rat monoxénique hébergeant l'Actinobacillus, l'uréolyse débute dans les fèces en même temps qu'apparaissent les premières bactéries, soit 6 heures après l'ensemencement de la souche et elle est totale 4 heures plus tard, alors que la population bactérienne a atteint son maximum, soit 5. IO $^{B}$ bactéries/g de fèces fraîches.

Chez le rat monoxénique hébergeant le Lactobacillus, les premières bactéries apparaissent 6 heures après l'ensemencement, la population atteint son maximum, soit $10^{9}$ bactéries/g de fèces fraîches, 2 heures plus tard, mais l'uréolyse ne débute que 12 heures après l'ensemencement pour atteindre son maximum 9 heures plus tard.

Le dosage de l'urée dans les différents compartiments du tube digestif des deux types de rats monoxéniques montre qu'il reste toujours de l'urée dans l'estomac et l'intestin grêle, alors que l'uréolyse devient totale à partir du cæeum.

In vitro, l'hydrolyse de l'urée s'observe seulement à la fin de la croissance chez le Lactobacillus, alors qu'elle commence dès le début de la croissance chez l'Actinobacillus. Les $\mathrm{pH}$ optimum d'action des uréases de ces 2 bactéries sont très différentes : 6,0 pour l'uréase de l'Actinobacillus et 2,5 à 3,0 pour l'uréase du Lactobacillus. On peut penser que ces bactéries exercent leur effet uréolytique à des niveaux différents du tube digestif : estomac pour le Lactobacillus et cæcum pour l'Actinobacillus.

$2^{\circ}$ Des rats porteurs d'une monoflore de Lactobacillus uréolytiques sont immunisés avec différents types d'antigènes. Si on les vaccine avec une suspension des mêmes bactéries qu'ils hébergent, ou avec un extrait protéique total de ces bactéries, on peut observer l'apparition dans les fèces et le cæcum des animaux d'une concentration d'urée qui est, dans certains cas, 
identique à celle trouvée chez les axéniques. Par contre, si l'antigène est constitué par un extrait protéique total provenant d'un mutant non uréolytique de la même souche de Lactobacillus, on n'observe pas d'apparition d'urée dans les fèces. Le mécanisme de l'inhibition de l'uréolyse est donc bien lié à l'immunisation par l'uréase. Enfin, si l'antigène est constitué par de l'uréase végétale, on observe une apparition d'urée dans les fèces beaucoup plus lente et plus réduite que dans le cas où l'antigène contient l'uréase du Lactobacillus.

$\mathrm{Si}$ on vaccine des animaux monoxéniques hébergeant l'Actinobacillus avec une suspension. de ces mêmes bactéries, on n'observe pas d'apparition d'urée dans les fèces.

Dans aucun cas on n'a observé une modification du nombre des bactéries dans les fèces et le tube digestif après immunisation.

Ces premiers résultats indiquent qu'il est possible, par l'immunisation, d'inhiber in vivo l'activité enzymatique d'une population bactérienne du tube digestif sans faire varier la taille de celle-ci. Mais, pour une même activité enzymatique, cet effet inhibiteur dépend de la souche bactérienne considérée.

\section{SUMMARY}

\section{UREOLYSIS BY VARIOUS BACTERIA IN VITRO AND IN VIVO \\ IN THE DIGESTIVE TRACT OF " GNOTOXENIC " RATS : EFFECT OF IMMUNIZATION}

The axenic rat excretes in its faeces about $40 \mathrm{mg}$ of urea per $100 \mathrm{~g}$ of fresh faeces, while no urea is found in the faeces of holoxenic animals. We tried to find out which bacterial strains present in the digestive tract of holoxenics are responsible for ureolysis. Moreover, we tried to modify this ureolytic activity by immunological means.

r. A strain of Lactobacillus and a strain of Actinobacillus, which were ureolytic in vitro, were isolated from the digestive tract of holoxenic rats. The digestive tract of axenic rats was implanted with each of these strains, and the hydrolysis kinetics of urea was followed in the faeces.

In the monoxenic rat carrying Actinobacillus, ureolysis in the faeces begins at the same time as the first bacteria appear, that is 6 hours after implantation of the strain, and it is total 4 hours later when the bacterial population reaches a maximum, i.e. $5 \cdot$ Io $^{8}$ bacteria/g of fresh faeces.

In the monoxenic rat carrying Lactobacillus, the first bacteria appear 6 hours after implantation; the population reaches its maximum, that is $10^{9}$ bacteria/g of fresh faeces, 2 hours later, but ureolysis only begins 12 hours after implantation and reaches a maximum 9 hours later.

The determination of urea in the different compartments of the digestive tract of two types of monoxenic rats shows that there is always urea in the stomach and small intestine, while ureolysis is total in the caecum.

Urea hydrolysis is seen in vitro only at the end of growth in Lactobacillus, while it starts at the beginning of growth in Actinobacillus. The optimum $\mathrm{pH}$ of urease action of these 2 bacteria is very different : 6.0 for Actinobacillus urease and 2.5, 3.0 for Lactobacillus urease. It may be that these bacteria exercise their ureolytic effect at various levels of the digestive tract : stomach for Lactobacillus and caecum for Actinobacillus.

2. Rats carrying anureolytic Lactobacillus monoflora were immunized with various kinds of antigens. If they were vaccinated with a suspension of the same bacteria they carried, or with a total protein extract of these bacteria, a concentration of urea appeared in the faeces and the caecum of these animals which, in some cases, was identical to that found in the axenics. 
On the other hand, if the antigen was composed of a total protein extract from a non-ureolytic mutant of the same strain of Lactobacillus, urea did not appear in the faeces. The ureolysis inhibiting mechanism is thus linked to urease immunization. Finally, if the antigen was composed of a plant urease, urea appeared much more slowly and in smaller quantities than when the antigen contained Lactobacillus urease.

\title{
PRODUCTION D'ACIDES GRAS VOLATILS PAR DES BaCtéries ANAÉRobies STHICTES \\ DANS LE TUBE DIGESTIF DE SOURIS « GNOTOXÉNIQUES ». EFFET INHIBITEUR SUR « SHIGELLA FLEXNERI »
}

M. RIOTTOT, R. DUCluzeaU*, P. RAIBAUD*, A. PERROT** et M. C. MYNARD

\author{
Groupe des Laboratoires de Gif sur Yvette, \\ C. N. R. S. 91 - Gif sur Yvette \\ * Laboratoire d'Écologie microbienne, \\ Centre national de Recherches zootechniques, I. N. R. A., \\ 78350 Jouy en Josas \\ ** Institut A. Merieux, 254, rue Marcel Mérieux, \\ 69 Lyon $(7 \mathrm{e})$
}

On a ensemencé dans le tube digestif de souris axéniques diverses souches de bactéries anaérobies strictes, productrices in vitro d'acides gras volatils (AGV), ou divers mélanges bactériens provenant de la microflore d'animaux holoxéniques. On a ensuite mesuré la production in vivo d'AGV dans le cæcum ou les fèces de ces animaux gnotoxéniques et on a étudié l'effet inhibiteur des AGV ainsi produits sur une couche de Shigella flexneri.

Nous avons constaté qu'il y a peu de relation entre la production d'AGV in vitro par des souches bactériennes et les concentrations d'AGV présentes dans le cæcum des animaux ensemencés avec des souches in vivo. Certaines souches seulement sont de bonnes productrices d'AGV et si l'on cumule dans un même animal des souches faibles productrices on n'additionne pas leurs productions. Des concentrations cæcales et fécales d'AGV du même ordre que celles que l'on mesure chez les holoxéniques, n'ont été obtenues qu'avec des gnotoxéniques hébergeant un mélange complexe de souches anaérobies strictes thermorésistantes non identifiées.

Chez ces animaux "gnotoxéniques ", on observe en fonction du temps des variations énormes des concentrations cæcales et fécales d'AGV. Ces variations sont même supérieures à ce qu'elles sont chez les holoxéniques. La teneur maximum en AGV dans le cæcum d'animaux gnotoxéniques peut parfois s'observer plusieurs semaines après l'établissement des souches productrices et l'addition de lactose au régime n'influe pas sur la production de ces AGV.

Enfin, on peut affirmer que la corrélation entre la production d'AGV et l'élimination de S. flexneri est très faible. Cette souche est en effet éliminée très efficacement par une flore complexe avant toute production importante d'AGV dans le cæcum alors qu'une autre flore, forte productrice d'AGV quelques semaines après l'ensemencement, n'a qu'un effet antagoniste très limité. 